\begin{abstract}
The feeding habits of the sicklefin smoothhound (Mustelus lunulatus) were studied on the basis of analysis of stomach contents of 314 specimens, allowing the diet of this species to be determined by sex, size, and stage of sexual maturity and for changes in the dietary ontogeny to be identified. The prey-specific index of relative importance revealed that the sicklefin smoothhound is a crab predator. Female and male sicklefin smoothhounds consumed a swimming crab species, Achelous iridescens, in similar proportions. Adults and juveniles of both sexes complemented their diets with the Panama mantis shrimp (Squilla panamensis), the dart squid, Lolliguncula (Loliolopsis) diomedeae, and the crab species Euphylax robustus, indicating behavioral and habitat segregation. Ontogenetic changes in diet were identified, with juveniles feeding almost exclusively on $A$. iridescens and adults having a more varied diet. The diet of sicklefin smoothhounds also changed with size: sharks $\leq 90 \mathrm{~cm}$ in total length (TL) consumed more A. iridescens, and sharks $>90 \mathrm{~cm}$ TL fed on a wider variety of prey. These results indicate that the sicklefin smoothhound is a selective mesopredator in the coastal marine food chain, having a significant influence on populations of benthic crustaceans in the southeastern Pacific Ocean.
\end{abstract}

Manuscript submitted 31 October 2018. Manuscript accepted 21 August 2019. Fish. Bull. 117:245-257 (2019).

Online publication date: 30 August 2019. doi: 10.7755/FB.117.3.11

The views and opinions expressed or implied in this article are those of the author (or authors) and do not necessarily reflect the position of the National Marine Fisheries Service, NOAA.

\title{
Trophic ecology and ontogenetic shift in the diet of the sicklefin smoothhound (Mustelus Iunulatus) in the southeastern Pacific Ocean
}

\author{
José S. Méndez-Macías ${ }^{1}$ \\ Vanessa M. Velázquez-Chiquito ${ }^{1}$ \\ Colombo Estupiñán-Montaño (contact author) ${ }^{2}$ \\ Felipe Galván-Magaña ${ }^{3}$ \\ Email address for contact author: goliathcem@gmail.com \\ ${ }^{1}$ Facultad Ciencias del Mar \\ Universidad Laica "Eloy Alfaro" de Manabí \\ Avenida Circunvalación, Vía a San Mateo \\ Manta, Manabí, Ecuador \\ ${ }^{2}$ Fundación Alium Pacific \\ Carrera 26 No. 5C-13 \\ Santiago de Cali, Valle del Cauca, Colombia \\ ${ }^{3}$ Centro Interdisciplinario de Ciencias Marinas \\ Instituto Politécnico Nacional \\ Avenida Instituto Politécnico Nacional s/n \\ Colonia Playa Palo de Santa Rita \\ 23096 La Paz, Baja California Sur, Mexico
}

Sharks generally occupy high positions in the food chain (Cortés, 1999), and some play an important role as regulators of lower trophic positions (Stevens et al., 2000; Heithaus et al., 2008; Ferretti et al., 2010). Such top-down control can be key to maintaining the health of the marine ecosystem because a decline in top-level predator populations can lead to trophic cascades, thereby changing the abundance of lower trophic-level populations (Ferretti et al., 2010). For example, some authors have hypothesized that the removal of sharks can cause a significant increase in the biomass of smaller sharks (mesopredators), sea turtles, sea birds, and fishes (Heithaus et al., 2010).

Understanding the ecological role of a species in an ecosystem depends mostly on knowing its trophic relationships (Braga et al., 2012). The trophic ecology of a species can in turn provide the information required for studies on resource sharing, competition, energy transfer, and food web dynamics (Navia et al., 2010; Bornatowski et al., 2014a). These more complex approaches rely on basic diet descriptions and are affected by the lack of basic knowledge of the diet of fish species (Bornatowski et al., 2014b). Understanding the trophic interactions and positions of large predators within food webs is a crucial step toward unraveling the dynamics of marine communities and the effect of sharks on different food web components (Lucifora et al., 2009; Heithaus et al., 2013).

The sicklefin smoothhound (Mustelus lunulatus) is an abundant species in warm temperate and tropical waters of the eastern Pacific Ocean (Compagno, 1984). This species typically inhabits muddy bottoms (Fernández, 1975) of the continental shelf and offshore areas (Compagno, 1984; Fischer et al., 1995) and feeds mainly 
on benthic crustaceans (Gómez et al., 2003; Navia et al., 2007; Moreno-Sánchez et al., 2012). The sicklefin smoothhound is a placental viviparous species (Compagno, 1984) that reaches a maximum total length (TL) of approximately $170 \mathrm{~cm}$ (Compagno, 1984). Mature females and males typically have TLs of approximately 103.2 and $91.5 \mathrm{~cm}$, respectively (Pérez-Jiménez and Sosa-Nishizaki, 2010), and the TL at birth is 32-35 mm (Compagno, 1984). Despite its abundance, little is known about the biology and ecology of the sicklefin smoothhound. Studies on the trophic ecology of sharks are scarce in Ecuador, and no research on the sicklefin smoothhound has been undertaken. Therefore, this study is the first to address the trophic ecology of this shark species in this region. The objectives of this study were 1) to collect quantitative dietary information for sicklefin smoothhounds, 2) to test for ontogenetic shifts in diet between stages of sexual maturity and size classes, and 3) to estimate the relative trophic position of sharks. Because of the rapid decline in the populations of several shark species (Bornatowski et al., 2014b), it is critical that we build our understanding of these patterns and processes to develop appropriate conservation strategies.

\section{Materials and methods}

We analyzed the stomach contents of 314 specimens of the sicklefin smoothhound. All sharks were caught by the artisanal fishery in Ecuador with gill nets and longlines in depths of 80-90 $\mathrm{m}$ along the continental platform and were landed in the port of Manta in Manabí, Ecuador, between November 2003 and October 2004 (Fig. 1).

For each specimen, natural TL (Francis 2006) was measured in centimeters and sex was determined before the digestive tract was extracted. Stomach contents were removed and filtered through a 1.5-mm mesh sieve, stored in plastic bags, and preserved on ice for transportation to the laboratory.
The prey were identified to the lowest taxon possible (on the basis of the digestion state of prey), counted, and weighed in grams. The prey species (i.e., complete organisms, skeletons, and otoliths) were identified according to Clothier (1950), Fischer et al. (1995), Chirichigno and Vélez (1998), and García-Godos (2001). The cephalopod species were identified by using their beaks (mandible) according to Wolff (1984) and Clarke (1986), and crustacean species were identified by their exoskeleton by using the keys from Garth (1973) and Fischer et al. (1995).

\section{Cumulative prey curve}

To determine whether the number of stomachs was sufficient to adequately describe the diet of sicklefin smoothhounds, a cumulative prey curve was constructed. The observed number of each prey item in the stomachs was used to estimate the value of the Shannon-Wiener diversity index for each stomach, and the samples were randomized 500 times with a sample-based rarefaction routine by using the software EstimateS, vers. 9 (Colwell, 2013). The coefficient of variation (0.05) was the basis for determining whether the number of stomachs was sufficient.

\section{Dietary analyses}

To assess the importance of the different prey taxa in the diet of sicklefin smoothhounds (overall and by sex, stage of sexual maturity, size class, and trimester), the preyspecific index of relative importance $\left(P S I R I_{\mathrm{i}}\right)$ (Brown et al., 2012), a modification of the index of relative importance (IRI) proposed by Pinkas et al. (1971) was used, according to this equation:

$$
P S I R I_{\mathrm{i}}=\frac{\% F O_{\mathrm{i}} \times\left(\% P N_{\mathrm{i}}+\% P W_{\mathrm{i}}\right)}{2},
$$

where $\% F O_{i}$ is the percent frequency of occurrence of a specific prey in all samples and $\% P N_{\mathrm{i}}$ and $\% P W_{\mathrm{i}}$ are the substitution of IRI's prey percent number and prey percent weight with their corresponding prey-specific abundances. Unlike the IRI, the PSIRI is cumulative with respect to taxonomic levels. The PSIRI of a major taxon is equal to the sum of the PSIRI of the items belonging to that taxon (Brown et al., 2012).

Stages of sexual maturity were determined on the basis of Pérez-Jiménez and Sosa-Nishizaki (2010), who report that the average size of sicklefin smoothhounds at sexual maturity in their study was $103.2 \mathrm{~cm}$ TL for females and $91.5 \mathrm{~cm}$ TL for males. The specimens caught were between 63 and $142 \mathrm{~cm}$ TL. They were grouped into 3 size classes (of both sexes) with a constant length range: $60-90 \mathrm{~cm}$ TL (Size I), 90-120 cm TL (Size II), and 120-150 cm TL (Size III). 
The specimens collected during November 2003October 2004 were grouped by trimester in chronological order: November 2003-January 2004 (Trimester I), February 2004-April 2004 (Trimester II), May 2004-July 2004 (Trimester III), and August 2004-October 2004 (Trimester IV). The information was grouped in this way in order to obtain a significant quantity for each trimester of the year.

To test for ontogenetic shifts in diet, a Bray-Curtis similarity matrix was constructed by using standardized estimates of the contribution of each prey taxon to the diet based on abundance (number of samples $[n]$ ). A one-way analysis of similarities (ANOSIM) was then performed, by using individuals as samples and stages of sexual maturity (sexes separated) and size classes (sexes combined) as factors. This test is analogous to analysis of variance and was used to evaluate similarity (or difference) within predefined groups (factors) versus similarity between groups and to calculate the statistic $R$, which varies between -1 and +1 (Clarke and Gorley, 2006). A post-hoc multiple comparison test (Benfferroni test) was then performed to identify specific differences between categories.

A nonmetric multidimensional scaling analysis was used to determine the maturity differences by diet and to determine the size-class dietary changes that occurred. Similarity percentage (SIMPER) analysis was used to estimate the contribution of each prey category to ontogenetic differences in diet. The analyses were performed by using the software PAST, vers. 3.14 (Hammer, 2001).

\section{Dietary niche breadth, overlap, and trophic position}

Dietary niche breadth was estimated by using Levin's index $\left(B_{\mathrm{i}}\right)($ Krebs, 1999):

$$
B_{\mathrm{i}}=\frac{1}{\Sigma P_{\mathrm{j}}^{2}},
$$

where $P_{\mathrm{j}}$ is the fraction (in PSIRI) of each food item in the diet $j\left(\Sigma P_{\mathrm{j}}=1\right)$. The $B_{\mathrm{i}}$ values were standardized to $B_{\mathrm{A}}$ so that they ranged from 0 to 1 by using this equation: $B_{\mathrm{A}}=\left(B_{\mathrm{i}}-1\right)(N-1)^{-1}$, where $N$ is the number of classes (Krebs, 1999). Low $B_{\mathrm{A}}$ values indicate diets dominated by few prey items (i.e., selective predators), and values close to 1 indicate opportunistic, generalist diets.

Trophic overlap was assessed by calculating the Morisita-Horn index $(C \lambda)$ (Smith and Zaret, 1982) to detect possible differences in diet between sexes, stages of sexual maturity, and size classes:

$$
C \lambda=2 \frac{\sum_{i=1}^{n}\left(P_{\mathrm{xi}} \times P_{\mathrm{yi}}\right)}{\sum_{i=1}^{n} P_{\mathrm{xi}}^{2}+\sum_{i=1}^{n} P_{\mathrm{yi}}^{2}},
$$

where $P_{\mathrm{xi}}$ is the proportion of $i^{\text {th }}$ prey with respect to all prey of predator $x, P_{\mathrm{yi}}$ is the proportion of the $i^{\text {th }}$ prey with respect to predator $y$, and $n$ is the total number of prey species. This index ranges from 0 to 1 , with values close to 0 indicating dietary differences and values close to 1 indicating similarity in prey consumed.
Standardized trophic position (TP) was calculated by using the trophic index proposed by Cortés (1999):

$$
T P_{\mathrm{k}}=1+\left(\sum_{i=1}^{n} P_{\mathrm{j}} \times T P_{\mathrm{j}}\right)
$$

where $n$ is the number of prey, $T P_{\mathrm{j}}$ is the trophic position of each prey taxon $j$ (Cortés, 1999), and $P_{\mathrm{j}}$ is the proportion of each prey category $j$ in the predator's diet, based on IRI values (percentages) (Bornatowski, 2014a). The trophic positions of all prey were taken from Cortés (1999), Hobson and Welch (1992), Sea Around Us (Pauly and Zeller ${ }^{1}$ ), and FishBase (Froese and Pauly ${ }^{2}$ ).

For all analyses, the crustacean, fish, and squid remains and unidentified organic matter were not considered because it was not possible to identify them with precision.

\section{Results}

A total of 314 stomachs were collected from specimens of the sicklefin smoothhound measuring 63-142 cm TL, and $95.2 \%(n=299)$ of the stomachs contained food. Of these stomachs, 171 were taken from females (69-142 cm TL) and 143 were taken from males $(63-118 \mathrm{~cm}$ TL), with $96.5 \%(n=165)$ and $93.7 \%(n=134)$ of the stomachs containing food, respectively.

Regarding the stages of sexual maturity, there were 90 juvenile females and 81 adult females, of which $96.7 \%$ and $96.3 \%$, respectively, had food in their stomachs. Of the 54 juvenile males and 90 adult males, $88.9 \%$ and $96.7 \%$, respectively, had food in their stomachs.

When examined by size class, $91.0 \%(n=100)$ of the Size-I sharks (60-90 cm TL), 97.3\% ( $n=183)$ of the Size-II sharks $(90-120 \mathrm{~cm}$ TL), and $96.9 \%(n=32)$ of the Size-III sharks (120-150 cm TL) had food in their stomachs.

In addition, of the specimens studied in Trimester I, Trimester II, Trimester III, and Trimester IV, 91.6\% $(n=87)$, $98 \%(n=58), 92 \%(n=73)$, and $100 \%(n=81)$, respectively, contained food in their stomachs.

\section{Cumulative prey curve}

The coefficient of variation indicates that all the cumulative prey curves approached their asymptote. This finding indicates that sample sizes were sufficient to adequately describe the diet of sicklefin smoothhounds (Fig. 2A). Indeed, the minimum number of stomachs required was 58 for females (51 for juveniles and 44 for adults; Fig. 2, $\mathrm{B}, \mathrm{D}$, and F) and 75 for males (44 for juveniles and 38 for adults; Fig. 2, C, E, and G).

\footnotetext{
${ }^{1}$ Pauly, D., and D. Zeller (eds.). 2015. Sea Around Us concepts, design, and data. [Available from website, accessed June 2016].

2 Froese, R., and D. Pauly. 2016. FishBase, vers. 06/2016. World Wide Web electron. publ. [Available from website, accessed June 2016].
} 


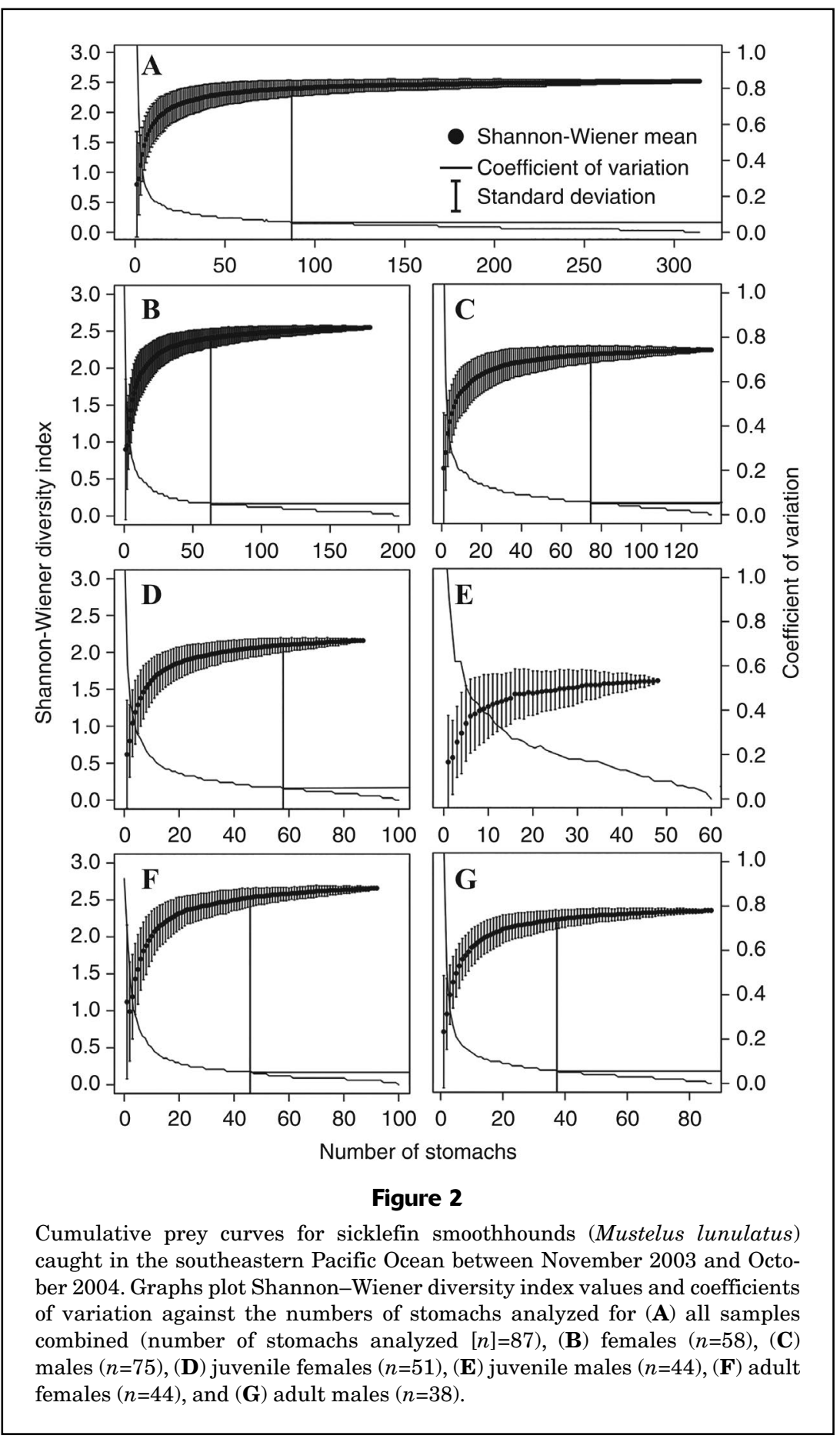

mantis shrimp (Squilla panamensis) and dart squid, Lolliguncula (Loliolopsis) diomedeae, and the males also consumed a small proportion of purse crabs (Iliacantha spp.) and small arched box crab (Calappula saussurei) (Table 2).

The dietary analysis by stage of sexual maturity revealed that the main prey of both juvenile and adult sicklefin smoothhounds was $A$. iridescens. Adult females, however, incorporated in their diet the dart squid, the small arched box crab, and a swimming crab, Euphylax robustus, and adult males complemented their diet with prey such as the small arched box crab, Iliacantha spp., and the crab Acanthocarpus delsolari (Fig. 3).

The dietary analysis of sicklefin smoothhounds also showed that Size-I sharks fed mostly on crustaceans: Achelous iridescens (PSIRI: 42.2\%), Iliacantha spp. (4.8\%), small arched box crab (3.9\%), and Panama mantis shrimp $(3.7 \%)$. In addition to A. iridescens $(26.6 \%)$, Size-II sharks ate Iliacantha spp. (7.7\%), small arched box crab (5.7\%), Panama mantis shrimp (3.8\%), and dart squid $(3.4 \%)$. Size-III sharks had a more varied diet composed of $E$. robustus (11.9\%), dart squid (10.9\%), Acanthocarpus delsolari (9.3\%), Panama mantis shrimp (8.6\%), and Achelous iridescens (7.5\%) (Fig. 4).

The dietary analysis by trimester indicated that crustaceans were the principal prey consumed by sicklefin smoothhounds throughout the year. By trimester, the importance of some species changed. The importance of the crustacean $A$. iridiscens increased from Trimester I to Trimester IV; however, the second crustacean in importance, the Panama mantis shrimp, decreased in importance throughout the year. For other crustaceans and for cephalopods, changes were minimal (Fig. 5).

Ontogenetic changes were identified in the diet of sicklefin smoothhounds, by stage of sexual maturity (global coefficient of multiple correlation $[R]=0.035$,

\section{Dietary analyses}

The examination of stomachs revealed that the diet of sicklefin smoothhounds was composed mostly of crustaceans and, in a lower proportion, of mollusks and teleosts (Table 1). The main prey were a swimming crab, Achelous iridescens, and crab species of the genus Iliacantha. (Table 1). Both sexes fed mostly on A. iridescens, but the females also consumed a small proportion of Panama
$P=0.002$ ), because of dietary differences between female adults with respect to female juveniles and male adults (Benfferroni test, corrected: $P=0.02$ ) as well as between female juveniles and male adults (Benfferoni test, corrected: $P=0.01$ ) (Fig. $6 \mathrm{~A}$ ).

Likewise, ontogenetic changes were observed by size class (global $R=0.043, P=0.006$; Figs. 4 and $6 \mathrm{~B}$ ). The results of the SIMPER analysis by stage of sexual maturity and size class are given in Table 3 . 


\section{Table 1}

Diet composition for sicklefin smoothhounds (Mustelus lunulatus) in the southeastern Pacific Ocean, based on analysis of stomach contents of specimens collected from landings of an artisanal fishery at the port of Manta, Ecuador, between November 2003 and October 2004. Values provided for prey found in stomachs include percent abundance (percent number of samples [\%N]), percent prey-specific abundance (percent number of samples for specific prey [\%PN]), percent weight (\%W), percent prey-specific weight (percent weight of specific prey [\% PW]), percent frequency of occurrence (\%FO), and prey-specific index of relative importance (PSIRI). Trophic position (TP) values are taken from Hobson and Welch (1992), Cortés (1999), Sea Around Us (2015), and FishBase (2016). A dash indicates that data were not available because a value was not estimated.

\begin{tabular}{|c|c|c|c|c|c|c|c|}
\hline Prey & $\% \mathrm{~N}$ & $\% \mathrm{PN}$ & $\% \mathrm{~W}$ & $\% \mathrm{PW}$ & $\% \mathrm{FO}$ & PSIRI $(\%)$ & $\mathrm{TP}$ \\
\hline ARTHROPODA & 88.17 & 90.59 & 89.03 & 91.48 & 97.32 & 88.60 & 2.52 \\
\hline Guyanacaris caespitosa & 0.11 & 33.33 & 0.18 & 53.54 & 0.30 & 0.15 & 3.43 \\
\hline Acanthocarpus delsolari & 4.29 & 64.17 & 4.20 & 62.74 & 6.70 & 4.25 & 2.52 \\
\hline Calappula saussurei & 5.13 & 36.51 & 4.43 & 31.54 & 14.00 & 4.78 & 3.60 \\
\hline Cycloes bardii & 0.17 & 50.00 & 0.23 & 67.90 & 0.30 & 0.19 & 2.52 \\
\hline Ethusa spp. & 2.40 & 34.22 & 2.29 & 32.63 & 7.00 & 2.34 & 2.60 \\
\hline Euphylax robustus & 1.99 & 37.28 & 2.77 & 51.84 & 5.30 & 2.36 & 4.00 \\
\hline Diogenidae & 0.07 & 20.00 & 0.03 & 8.88 & 0.30 & 0.05 & 2.50 \\
\hline Penaeidae & 0.02 & 6.67 & $<0.01$ & 0.48 & 0.20 & 0.01 & 3.31 \\
\hline Goneplax spp. & 0.44 & 26.38 & 0.51 & 30.79 & 1.70 & 0.49 & 2.82 \\
\hline Hemisquilla spp. & 0.08 & 25.00 & 0.01 & 1.53 & 0.30 & 0.04 & 3.50 \\
\hline Hepatus kossmanni & 0.08 & 25.00 & 0.10 & 30.35 & 0.30 & 0.09 & 2.60 \\
\hline Iliacantha spp. & 46.00 & 41.05 & 46.00 & 40.33 & 15.40 & 6.27 & 2.60 \\
\hline Mesorhoea belli & 0.83 & 31.15 & 0.47 & 17.38 & 2.70 & 0.66 & 2.52 \\
\hline Munida hispida & 0.11 & 33.33 & 0.07 & 22.17 & 0.30 & 0.09 & 3.10 \\
\hline Munida refulgens & 1.01 & 38.02 & 0.97 & 36.29 & 2.70 & 0.99 & 3.10 \\
\hline Panopeus spp. & 1.09 & 29.55 & 0.98 & 26.62 & 3.70 & 1.04 & 3.38 \\
\hline Parasquilla similis & 0.04 & 12.50 & 0.02 & 6.63 & 0.30 & 0.03 & 2.52 \\
\hline Parthenope spp. & 0.84 & 25.24 & 0.68 & 20.46 & 3.30 & 0.75 & 2.52 \\
\hline Pilumnus fernandezi & 0.87 & 43.52 & 0.85 & 42.34 & 2.00 & 0.86 & 2.52 \\
\hline Plesionika mexicana & 0.17 & 50.00 & 0.06 & 17.77 & 0.30 & 0.10 & 2.70 \\
\hline Platymera gaudichaudii & 1.52 & 64.76 & 1.53 & 65.37 & 2.30 & 1.50 & 2.52 \\
\hline Achelous iridescens & 30.16 & 60.12 & 29.12 & 58.05 & 50.20 & 29.66 & 3.40 \\
\hline Portunus asper & 0.84 & 83.33 & 0.91 & 90.99 & 1.00 & 0.87 & 3.40 \\
\hline Ranilia spp. & 1.09 & 36.28 & 1.05 & 34.90 & 3.00 & 1.07 & 2.52 \\
\hline Sicyonia disdorsalis & 0.06 & 16.67 & 0.04 & 11.24 & 0.30 & 0.05 & 2.40 \\
\hline Sicyonia picta & 0.21 & 31.25 & 0.16 & 23.25 & 0.70 & 0.19 & 2.40 \\
\hline Solenocera agassizi & 0.36 & 26.90 & 0.50 & 37.69 & 1.30 & 0.43 & 2.20 \\
\hline Solenocera spp. & 0.17 & 25.89 & 0.14 & 21.38 & 0.70 & 0.17 & 2.20 \\
\hline Squilla biformis & 0.81 & 48.33 & 0.80 & 48.02 & 1.70 & 0.82 & 3.50 \\
\hline Squilla hancocki & 0.37 & 27.92 & 0.22 & 16.16 & 1.30 & 0.29 & 3.50 \\
\hline Squilla panamensis & 4.22 & 40.08 & 4.36 & 43.46 & 10.00 & 4.29 & 3.50 \\
\hline Squilla spp. & 2.82 & 38.26 & 2.31 & 31.41 & 7.40 & 2.58 & 3.50 \\
\hline Rimapenaeus pacificus & 0.06 & 16.67 & 0.01 & 3.29 & 0.30 & 0.03 & 2.52 \\
\hline Trizocarcinus dentatus & 0.22 & 22.22 & 0.16 & 5.74 & 1.00 & 0.19 & 2.52 \\
\hline Crustacean remains & 19.18 & 48.19 & 22.66 & 56.93 & 39.80 & 20.92 & 2.52 \\
\hline OSTEICHTHYES & 5.87 & 39.89 & 5.39 & 36.59 & 14.72 & 5.63 & 3.24 \\
\hline Anchoa spp. & 0.26 & 77.78 & 0.14 & 43.02 & 0.33 & 0.20 & 3.25 \\
\hline Auxis spp. & 0.94 & 40.36 & 1.07 & 45.54 & 2.34 & 1.01 & 4.24 \\
\hline Bollmannia chlamydes & 0.17 & 50.00 & 0.28 & 82.23 & 0.33 & 0.22 & 3.50 \\
\hline Citharichthys gilberti & 0.17 & 50.00 & 0.08 & 25.33 & 0.33 & 0.13 & 4.10 \\
\hline Citharichthys platophrys & 0.08 & 25.00 & 0.03 & 10.29 & 0.33 & 0.06 & 3.50 \\
\hline Paralichthyidae & 0.03 & 9.09 & 0.02 & 5.21 & 0.33 & 0.02 & 4.06 \\
\hline Pleuronectiformes & 0.12 & 37.50 & 0.17 & 52.07 & 0.33 & 0.15 & 3.57 \\
\hline Unidentified fish & 0.56 & 55.56 & 0.51 & 50.40 & 1.00 & 0.53 & 3.24 \\
\hline Symphurus spp. & 0.15 & 22.92 & 0.05 & 6.99 & 0.67 & 0.10 & 3.30 \\
\hline Fish remains & 3.38 & 38.89 & 3.04 & 34.93 & 8.70 & 3.21 & 3.24 \\
\hline MOLLUSCA & 5.76 & 44.13 & 5.34 & 40.98 & 13.04 & 5.55 & 3.20 \\
\hline Gastropoda & 0.29 & 28.89 & 0.07 & 6.49 & 1.00 & 0.18 & 2.10 \\
\hline Lolliguncula (Loliolopsis) diomedeae & 4.01 & 45.36 & 3.69 & 40.83 & 9.03 & 3.89 & 3.90 \\
\hline Squid remains & 1.37 & 45.49 & 1.59 & 52.89 & 3.01 & 1.48 & 3.20 \\
\hline Unidentified organic matter & 0.20 & 20.37 & 0.23 & 23.28 & 1.00 & 0.22 & - \\
\hline
\end{tabular}




\section{Table 2}

Diet composition, by sex (with size classes and maturity stages combined), for sicklefin smoothhounds (Mustelus lunulatus) caught in the southeastern Pacific Ocean during November 2003-October 2004. Values provided for prey include percent prey-specific abundance (percent number of samples for specific prey [\% PN]), percent prey-specific weight (percent weight of specific prey $[\% \mathrm{PW}]$ ), percent frequency of occurrence $(\% \mathrm{FO})$, and prey-specific index of relative importance (PSIRI). A dash indicates that data were not available because the prey species was not consumed by both sexes.

\begin{tabular}{|c|c|c|c|c|c|c|c|c|}
\hline \multirow[b]{2}{*}{ Prey } & \multicolumn{2}{|c|}{$\% \mathrm{PN}$} & \multicolumn{2}{|c|}{$\% \mathrm{PW}$} & \multicolumn{2}{|c|}{$\% \mathrm{FO}$} & \multicolumn{2}{|c|}{ PSIRI (\%) } \\
\hline & Females & Males & Females & Males & Females & Males & Females & Males \\
\hline ARTHROPODA & 89.12 & 92.39 & 90.21 & 93.04 & 96.90 & 97.70 & 86.94 & 90.64 \\
\hline Guyanacaris caespitosa & 33.33 & - & 53.54 & - & 0.60 & - & 0.26 & - \\
\hline Acanthocarpus delsolari & 62.50 & 64.88 & 60.69 & 63.62 & 3.60 & 10.40 & 2.24 & 6.71 \\
\hline Calappula saussurei & 35.57 & 37.22 & 31.00 & 31.94 & 10.90 & 17.90 & 3.63 & 6.19 \\
\hline Cycloes bardii & 50.00 & - & 67.90 & - & 0.60 & - & 0.36 & - \\
\hline Ethusa spp. & 26.22 & 47.22 & 21.19 & 51.23 & 7.90 & 5.90 & 1.87 & 2.94 \\
\hline Diogenidae & - & 20.00 & - & 8.88 & - & 0.70 & - & 0.11 \\
\hline Euphylax robustus & 39.09 & 10.00 & 54.46 & 12.61 & 9.10 & 0.70 & 4.25 & 0.08 \\
\hline Penaeidae & 6.67 & - & 0.48 & - & 0.60 & - & 0.02 & - \\
\hline Goneplax spp. & 24.64 & 33.33 & 29.94 & 34.23 & 2.40 & 0.70 & 0.66 & 0.25 \\
\hline Hemisquilla spp. & 25.00 & - & 1.53 & - & 0.60 & - & 0.08 & - \\
\hline Hepatus kossmanni & 25.00 & - & 30.35 & - & 0.60 & - & 0.17 & - \\
\hline Iliacantha spp. & 40.19 & 41.83 & 40.66 & 40.03 & 13.30 & 17.90 & 5.39 & 7.33 \\
\hline Mesorhoea belli & 27.64 & 41.67 & 12.47 & 32.11 & 3.60 & 1.50 & 0.73 & 0.55 \\
\hline Munida hispida & - & 33.33 & - & 22.17 & - & 0.70 & - & 0.21 \\
\hline Munida refulgens & 22.50 & 43.19 & 22.32 & 40.95 & 1.20 & 4.50 & 0.27 & 1.88 \\
\hline Panopeus spp. & 30.00 & 25.00 & 28.57 & 7.18 & 6.10 & 0.70 & 1.77 & 0.12 \\
\hline Parasquilla similis & 12.50 & - & 6.63 & - & 0.60 & - & 0.06 & - \\
\hline Parthenope spp. & 26.06 & 23.33 & 24.55 & 10.89 & 4.20 & 2.20 & 1.07 & 0.38 \\
\hline Pilumnus fernandezi & 25.00 & 62.04 & 15.34 & 69.34 & 1.80 & 2.20 & 0.37 & 1.47 \\
\hline Platymera gaudichaudii & 55.00 & 77.78 & 55.61 & 78.39 & 2.40 & 2.20 & 1.34 & 1.75 \\
\hline Plesionika mexicana & - & 50.00 & - & 17.77 & - & 0.70 & - & 0.25 \\
\hline Achelous iridescens & 58.25 & 62.44 & 54.97 & 61.87 & 50.30 & 50.00 & 28.48 & 31.08 \\
\hline Portunus asper & 83.33 & - & 90.99 & - & 1.80 & - & 1.58 & - \\
\hline Ranilia spp. & 31.63 & 40.00 & 24.88 & 42.92 & 2.40 & 3.70 & 0.68 & 1.55 \\
\hline Squilla biformis & - & 48.33 & - & 48.01 & - & 3.70 & - & 1.79 \\
\hline Squilla hancocki & 18.33 & 37.50 & 3.19 & 29.12 & 1.20 & 1.50 & 0.13 & 0.49 \\
\hline Squilla panamensis & 43.43 & 36.67 & 46.63 & 30.80 & 14.50 & 4.50 & 6.55 & 1.51 \\
\hline Squilla spp. & 32.61 & 53.33 & 26.67 & 44.06 & 9.70 & 4.50 & 2.87 & 2.18 \\
\hline Solenocera agassizi & 14.29 & 31.11 & 12.95 & 45.94 & 0.60 & 2.20 & 0.08 & 0.86 \\
\hline Solenocera spp. & 37.50 & 14.29 & 19.21 & 3.56 & 0.60 & 0.70 & 0.17 & 0.14 \\
\hline Sicyonia disdorsalis & 16.67 & - & 11.24 & - & 0.60 & - & 0.08 & - \\
\hline Sicyonia picta & 31.25 & - & 23.25 & - & 1.20 & - & 0.33 & - \\
\hline Rimapenaeus pacificus & 16.67 & - & 3.29 & - & 0.60 & - & 0.06 & - \\
\hline Trizocarcinus dentatus & 22.22 & - & 15.74 & - & 1.80 & - & 0.35 & - \\
\hline Crustacean remains & 45.24 & 52.41 & 53.87 & 61.31 & 42.40 & 36.50 & 21.02 & 20.79 \\
\hline OSTEICHTHYES & 41.44 & 38.05 & 34.70 & 38.88 & 14.50 & 14.90 & 5.54 & 5.74 \\
\hline Anchoa spp. & 77.78 & - & 43.02 & - & 0.60 & - & 0.37 & - \\
\hline Auxis spp. & 41.67 & 39.83 & 49.10 & 44.12 & 1.20 & 3.70 & 0.55 & 1.57 \\
\hline Bollmannia chlamydes & - & 50.00 & - & 82.23 & - & 0.70 & - & 0.49 \\
\hline Citharichthys gilberti & 50.00 & - & 25.33 & - & 0.60 & - & 0.23 & - \\
\hline Citharichthys platophrys & 25.00 & - & 10.29 & - & 0.60 & - & 0.11 & - \\
\hline Paralichthyidae & - & 9.09 & - & 5.21 & - & 0.70 & - & 0.05 \\
\hline Unidentified fish & 58.33 & 50.00 & 52.47 & 46.26 & 1.20 & 0.70 & 0.67 & 0.36 \\
\hline Pleuronectiformes & 37.50 & - & 52.07 & - & 0.60 & - & 0.27 & - \\
\hline Symphurus spp. & 22.92 & - & 6.99 & - & 1.20 & - & 0.18 & - \\
\hline Fish remains & 39.89 & 37.73 & 34.64 & 35.27 & 8.40 & 8.90 & 3.16 & 3.27 \\
\hline MOLLUSCA & 43.92 & 44.65 & 43.85 & 33.66 & 16.90 & 8.20 & 7.45 & 3.21 \\
\hline Gastropoda & 16.67 & 35.00 & 4.81 & 7.34 & 0.60 & 1.50 & 0.07 & 0.32 \\
\hline Lolliguncula (Loliolopsis) diomedeae & 45.94 & 43.33 & 42.94 & 33.46 & 12.70 & 4.40 & 5.66 & 1.72 \\
\hline Squid remains & 41.39 & 53.70 & 53.54 & 51.60 & 3.60 & 2.20 & 1.73 & 1.18 \\
\hline Unidentified organic material & 16.67 & 22.22 & 6.56 & 31.64 & 0.60 & 1.50 & 0.07 & 0.40 \\
\hline
\end{tabular}



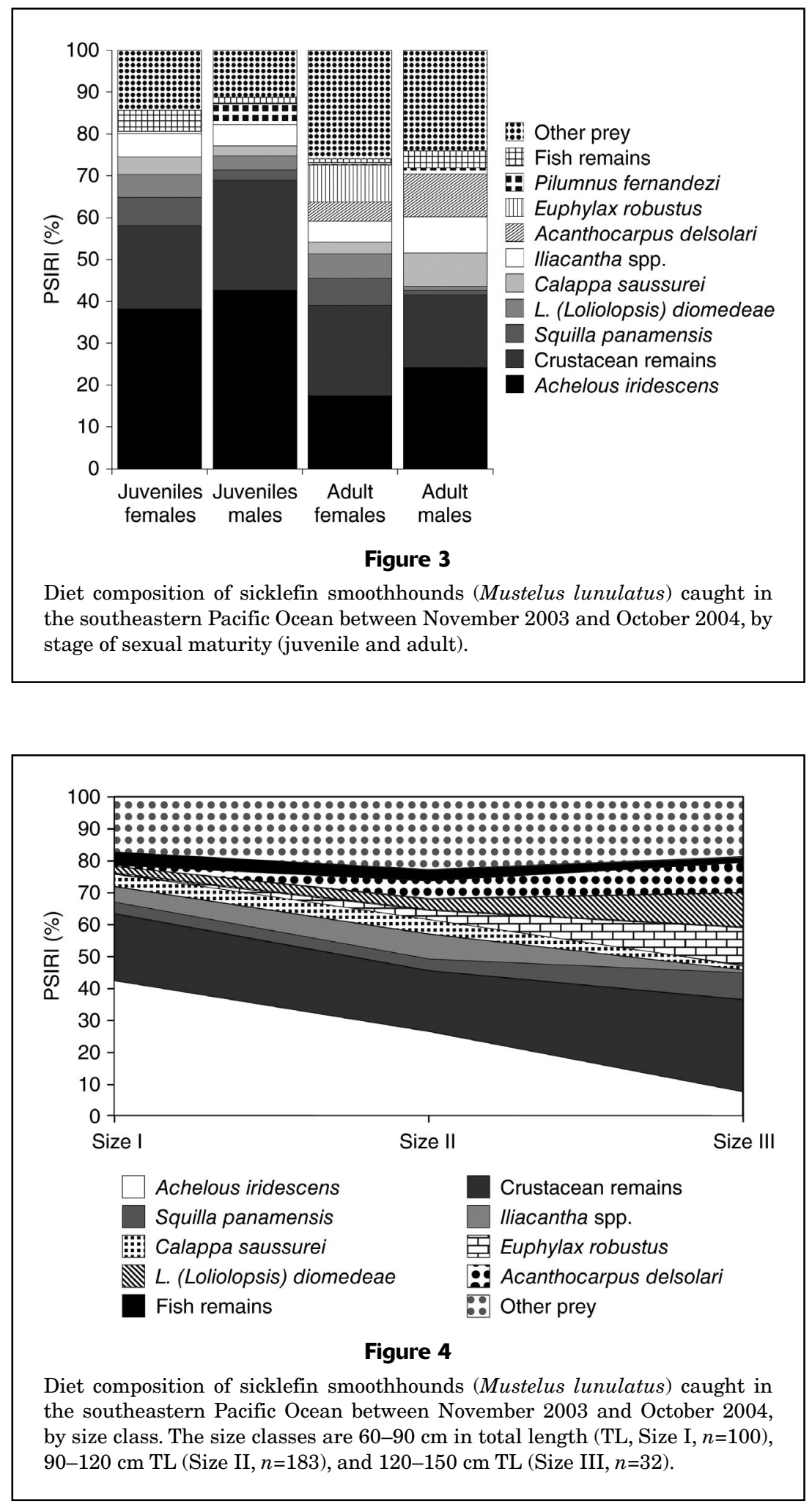

well as for the different stages of sexual maturity (Table 4), size classes (Table 5), and trimesters. The $B_{\mathrm{i}}$ values were 0.50 , $0.18,0.06$, and 0.05 for Trimesters I, II, III, and IV, respectively.

The trophic overlap index revealed high dietary overlap between the sexes $(C \lambda=0.92$, global $R=0.009, P=0.072)$. When applied to the stages of sexual maturity, this index showed that the diet of adult females significantly overlaped with that of juveniles, both females and males (Table 4). However, there was little trophic overlap between size classes (Table 5).

The estimated trophic position (3.59 [standard deviation (SD) 0.24]) indicates that the sicklefin smoothhound is a secondary consumer. Also, by sex, maturity stage (Table 4), and size class (Table 5), this species is a secondary consumer.

\section{Discussion}

The few studies on the trophic ecology of the sicklefin smoothhound mention that its diet includes crustaceans (e.g., shrimps, blue crabs, and other crabs), small fishes (e.g., anchovies and sardines), and, occasionally, mollusks (Fernández, 1975; Gómez et al., 2003; Navia et al., 2006; Navia et al., 2007), with crustaceans being the most important prey group. These results are in line with those of this study, allowing the sicklefin smoothhound to be classified as a carcinophagous predator.

Dietary studies of other members of Mustelus have shown that this taxon prefers crustaceans. The humpback smoothhound (M. whitneyi), for example, eats crabs of the families Calappidae and Portunidae and shrimps of the family Squillidae and consumes small proportions of seaweed, annelids, mollusks, and fishes (Samame et al., 1989). The brown smoothhound ( $M$. henlei) feeds mostly on crabs, shrimps (Squillidae), isopods, tunicates, cephalopods, and small fishes (e.g., Fischer et al., 1995; Gómez et al., 2003). These similarities in the diet of Mustelus species indicate that they prey on benthic crustaceans.

\section{Dietary niche breadth, overlap, and trophic position}

The standardized niche breadth index showed that the sicklefin smoothhound is a selective predator. This was the case for both females $\left(B_{\mathrm{A}}=0.06\right)$ and males $\left(B_{\mathrm{A}}=0.05\right)$, as
We found that the crabs A. iridescens and Iliacantha spp. were the main prey of sicklefin smoothhounds, similar to what was reported by Gómez et al. (2003) and Bohórquez-Herrera (2006) for Gorgona Island, Colombia. Our results are also consistent with those of studies 


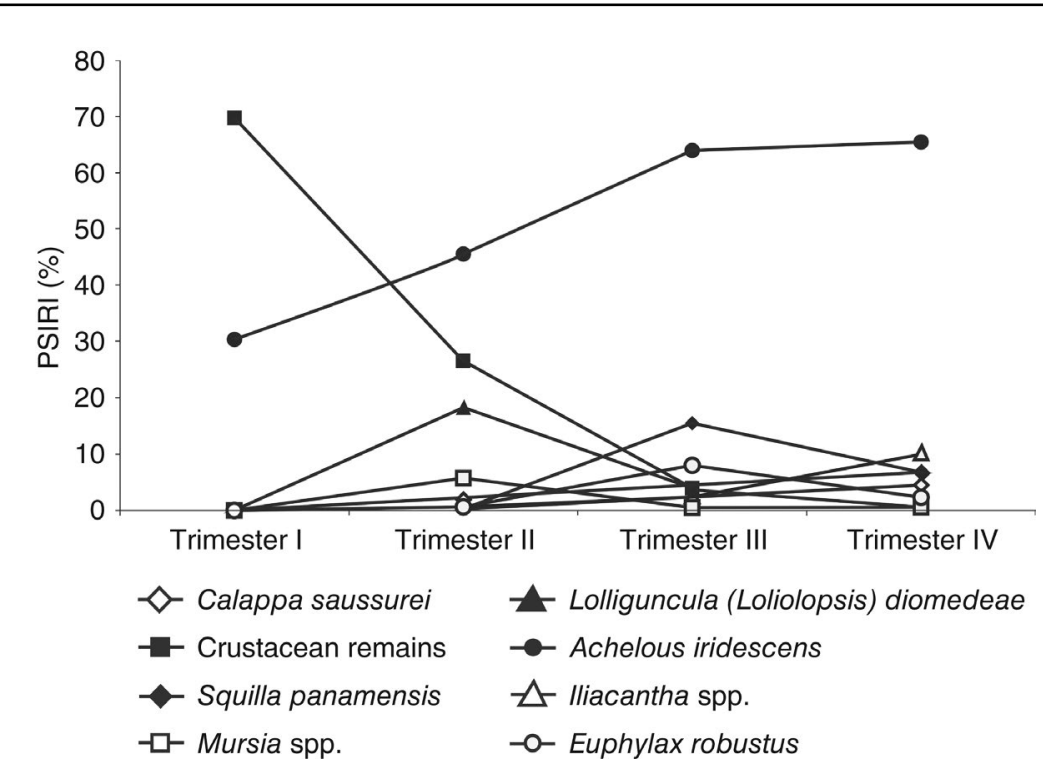

Figure 5

Diet composition of sicklefin smoothhounds (Mustelus lunulatus) caught in the southeastern Pacific Ocean between November 2003 and October 2004, by trimester of the year. The trimesters are November 2003-January 2004 (Trimester I), February 2004-April 2004 (Trimester II), May 2004-July 2004 (Trimester III), and August 2004-October 2004 (Trimester IV).

crab (Cancer amphioetus), 2 species that are distributed from Southern California in the United States to the Gulf of California in Mexico (Nations, 1975; Hendrickx, 2000).

A likely explanation of the large presence of $A$. iridescens in the stomachs of sicklefin smoothhounds in waters of Ecuador is the abundance of this species in the region, as found by Mora et al. (2010). That study demonstrated that the most abundant macroinvertebrates along the coast of Ecuador were A. iridescens, followed by the arched swimming crab (C. arcuatus), dart squid, C. toxotes, and the pink shrimp (Farfantepenaeus brevirostris). These observations and results indicate that 1 ) sicklefin smoothhounds feed primarily at depths between 80 and $200 \mathrm{~m}$ (where there is the greatest abundance of $A$. iridescens, according to Mora et al., 2010) and 2) this species is a selective one, a trait that is associated with the abundance and availability of prey in the zones that it inhabits.

The dietary analysis by sex revealed that both female and male sicklefin smoothhounds have a preference for $A$. iridescens, a result that, together with

examining other species of the genus Mustelus that indicate that their principal prey are crustaceans (Ellis et al., 1996; Rojas, 2006). The results of our study, however, differ from the findings of Rojas (2000), Navia et al. (2006), and Navia et al. (2007), who reported that shrimps of the family Squillidae (e.g., Panama mantis shrimp and Squilla parva) were the main prey of sicklefin smoothhounds along the Pacific coast of Colombia. In contrast, the results of our study indicate that, although these shrimp species were present, they contributed little to the diet of sicklefin smoothhounds. This discrepancy can probably be attributed to the small number of stomachs $(n=50, n=42)$ and size classes (mainly 50-70 cm TL) analyzed by Navia et al. (2006) and Navia et al. (2007), rather than to latitudinal variations that could affect the diversity and abundance of the main prey groups, because of the proximity of the localities studied. The distance between the location of this study (in Manta, Ecuador) and the location of the studies by Navia et al (2006) and Navia et al. (2007) (in Buenaventura, Colombia) is approximately $760 \mathrm{~km}$.

Furthermore, Gomez et al (2003) and Bohórquez-Herrera (2006) conducted similar studies in areas close to the area studied by Navia et al. (2006) and Navia et al. (2007), and their results also differ from those obtained by Navia et al. (2006) and Navia et al. (2007). An example of latitudinal variation is the contrast in results obtained in the study by Moreno-Sánchez et al. (2012), who reported that in Baja California Sur, Mexico, sicklefin smoothhounds fed mostly on a squat lobster, Munida tenella, and the bigtooth rock the high dietary overlap between the sexes $(C \lambda=0.92)$, indicates that there is no sexual segregation in this species. This finding agrees with the dietary overlap $(C \lambda=0.96)$ estimated by Moreno-Sánchez et al. (2012), despite the geographical differences between the 2 studies. Nonetheless, these results must be interpreted with caution because they could represent "false positives," as occurred in our study with the analysis of the values of trophic overlap by stage of maturity for separate sexes (Table 4) indicating that sicklefin smoothhounds present behavioral and habitat segregation (Wearmouth and Sims, 2008). However, juveniles of both sexes and female adults complement their principal diet (A. iridescens) with coastal benthic prey that are typically associated with shallow waters and muddy-sandy seabeds, such as E. robustus (7-85 m) (Hendrickx, 1995a) and Panama mantis shrimp (18-102 m) (Hendrickx, 1995b) and with coastal pelagic species, such as the dart squid (50-200 m) (Sánchez, 2003).

The use of different feeding areas by juveniles of both sexes and female adults could be related to selection of breeding areas, abundance and availability of prey, development of hunting skills by juveniles, preferences for particular foraging zones pertaining to sex (McCord and Campana, 2003), size class, stage of maturity, and access to alternative sources of nutrition (e.g., pelagic prey; Eder and Lewis, 2005) related to specific stages of individual growth (Philips, 1969; Tytler and Calow, 1985).

In contrast, male adult sicklefin smoothhounds prefer to complement their diet with the consumption of benthic coastal prey that exhibit a greater range of distribution, 


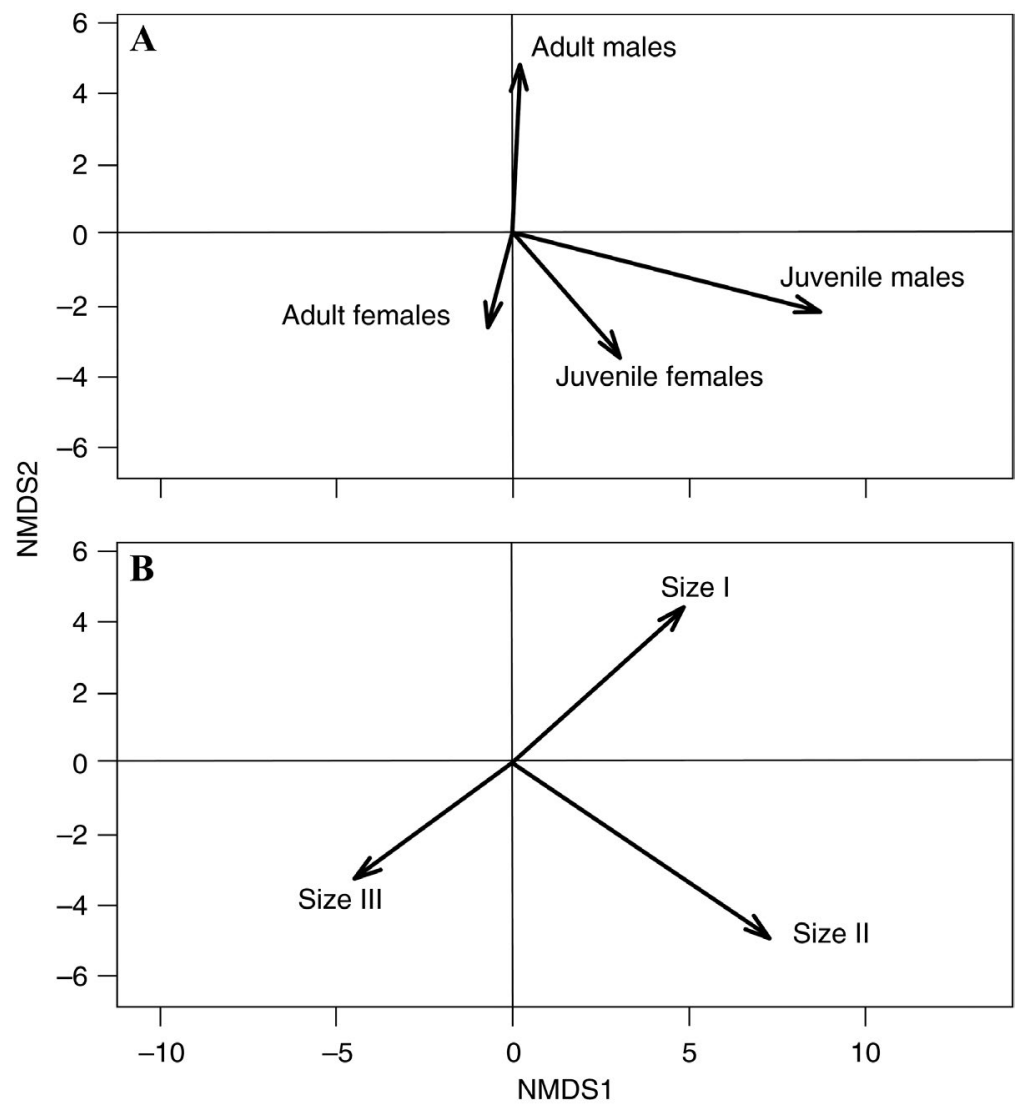

Figure 6

Nonmetric multidimensional scaling (MDS) ordination indicating the changes in diet of sicklefin smoothhounds (Mustelus lunulatus) caught in the southeastern Pacific Ocean between November 2003 and October 2004, for (A) maturity stages (juvenile and adult) and (B) size classes. The size classes are $60-90 \mathrm{~cm}$ in total length (TL, Size I), 90-120 cm TL (Size II), and 120-150 cm TL (Size III).

(in the case of females) as well as other crustacean species (in the case of males). These results indicate that adult sharks, with their larger size and better hunting skills, explore new areas (i.e., the pelagic zone) while they search for food. The consumption of different foods by sharks at different stages of sexual maturity may be associated with 1) different energy requirements, 2) reproductive processes, 3) cost-benefit tradeoffs, 4) prey availability, and 5) hunting skills.

To date, no trophic study of the sicklefin smoothhound had analyzed feeding patterns throughout the year. Therefore, this study is the first to have conducted an analysis that took into account the trophic spectrum of the sicklefin smoothhound in 4 trimesters. The results of our study indicate that this species prefers $A$. iridescens throughout the year. However, between November 2003 and January 2004 the prey consumed was dominated by crustaceans (PSIRI: 69.7\%), and in the other 3 trimesters the presence of A. iridescens increased in importance by 45-65\% (PSIRI) and there was a corresponding reduction in the presence of crustaceans (Fig. 5).

These results are consistent with the abundance of crustaceans estimated by Mora et al. (2010), who identified 150 species of macroinvertebrates (120 crustaceans, 15 mollusks, 13 echinoderms, and 2 cnidarians), with the most abundant species being a swimming crab, A. iridescens, followed by a cephalopod, the dart squid. These observations support our results that indicate that the sicklefin smoothhound is a species that

prey such as the small arched box crab, present at depths of 1-300 m (Hendrickx, 1997), and Acanthocarpus desolari, present at depths of 100-300 m (Del Rosario and Abele, 1976). These species typically inhabit seabeds formed from sand, mud, pebbles, stones, or dead coral (Hendrickx, 1997; Del Rosario and Abele, 1976).

Moreno-Sánchez et al. (2012) mentioned that juvenile and adult sicklefin smoothhounds fed on the same prey, but adults had a stronger preference for fish species. However, the authors analyzed juveniles and adults of both sexes combined, which may have obscured dietary patterns. In our study, for which the sexes were analyzed separately, both female and male juveniles were found to have a diet based on Achelous iridescens ( $>30 \%$ PSIRI; Fig. 3), a crustacean inhabiting sandy and muddy bottoms (Wehrtmann and Cortés, 2009) that can be easily captured by young sharks that are still developing their hunting skills. Adults (both female and male) ate less of this crustacean and complemented their diet with cephalopods specializes in the consumption of crustaceans that are highly abundant in the zone they inhabit. Because of the substantial presence of crustaceans in stomachs of specimens during November-January (Trimester I) and the greater number of individuals in Size I $(n=95)$ analyzed in the study period, we hypothesize that during this period juvenile individuals consume more small crustaceans that are easier to hunt and digest. Nonetheless, more studies are required, including research related 1) to abundance of prey species and (2) to other biological aspects of the sicklefin smoothhound (such as reproduction and growth) that would improve understanding of the spatial and temporal feeding behavior of this species.

The study of the diet of sicklefin smoothhounds by Moreno-Sánchez et al. (2012) may be the most detailed so far, and it found no ontogenetic changes in the diet of this species. Our study, in contrast, has revealed that the diet of sicklefin smoothhounds changes as they grow (Fig. 4) and become sexually mature (Fig. 3), from a diet composed 


\section{Table 3}

Contribution of prey to the similarity of diet, by sex, stage of sexual maturity, and size class, for sicklefin smoothhounds (Mustelus lunulatus) caught in the southeastern Pacific Ocean during November 2003-October 2004, based on similarity percentage analysis. The maturity stages are juvenile (J.) and adult (A.), and the size classes are 60-90 cm in total length (TL, Size I), 90-120 cm TL (Size II), and 120-150 cm TL (Size III). A dash indicates that data were not available because the prey species was not shared between categories.

\begin{tabular}{|c|c|c|c|c|c|c|c|c|c|}
\hline \multirow[b]{2}{*}{ Prey } & \multicolumn{9}{|c|}{ Combination } \\
\hline & $\begin{array}{l}\text { J. female vs. } \\
\text { A. female }\end{array}$ & $\begin{array}{l}\text { J. male vs. } \\
\text { A. male }\end{array}$ & $\begin{array}{l}\text { J. female } \\
\text { vs. J. male }\end{array}$ & $\begin{array}{l}\text { A. female } \\
\text { vs. A. male }\end{array}$ & $\begin{array}{l}\text { J. female } \\
\text { vs. A. male }\end{array}$ & $\begin{array}{l}\text { A. female } \\
\text { vs. J. male }\end{array}$ & $\begin{array}{l}\text { Size I vs. } \\
\text { Size II }\end{array}$ & $\begin{array}{l}\text { Size I vs. } \\
\text { Size III }\end{array}$ & $\begin{array}{l}\text { Size II vs. } \\
\text { Size III }\end{array}$ \\
\hline Dissimilarity (\%) & 86.28 & 84.00 & 80.40 & 88.48 & 82.67 & 85.23 & 82.37 & 89.30 & 90.92 \\
\hline Achelous iridescens & 34.52 & 39.24 & 45.82 & 27.29 & 33.46 & 39.00 & 38.46 & 28.78 & 25.35 \\
\hline $\begin{array}{l}\text { Lolliguncula (Loliol- } \\
\text { opsis) diomedeae }\end{array}$ & 9.19 & - & 8.52 & 5.36 & 5.66 & 8.38 & 5.67 & 11.73 & 10.87 \\
\hline Squilla panamensis & 8.43 & - & 7.11 & 5.25 & 5.34 & 7.11 & 5.41 & 10.16 & 9.11 \\
\hline Iliacantha spp. & 7.76 & 10.47 & 8.97 & 9.46 & 10.93 & 7.38 & 9.99 & - & 6.20 \\
\hline Calappula saussurei & 5.61 & 8.94 & 5.69 & 8.71 & 9.29 & - & 7.61 & - & 5.22 \\
\hline Mursia spp. & - & 6.97 & - & 9.17 & 6.31 & - & - & 9.66 & 9.67 \\
\hline Euphylax robustus & - & - & - & - & - & - & - & 6.39 & 6.54 \\
\hline Ethusa spp. & - & - & - & - & - & - & - & - & 5.17 \\
\hline Mollusks & 13.16 & 5.98 & 11.69 & 8.09 & 8.98 & 11.43 & 7.86 & 16.78 & 17.3 \\
\hline Crustaceans & 82.18 & 90.2 & 84.48 & 87.21 & 85.72 & 85.34 & 87.63 & 77.16 & 77.49 \\
\hline Fishes & 4.66 & 3.82 & 3.84 & 4.70 & 5.30 & 3.33 & 4.51 & 6.06 & 5.21 \\
\hline
\end{tabular}

\section{Table 4}

Dietary overlap between stages of sexual maturity, dietary niche breadth $\left(B_{\mathrm{A}}\right)$, and trophic position (TP) for sicklefin smoothhounds (Mustelus lunulatus) caught in the southeastern Pacific Ocean during November 2003-October 2004. An asterisk $\left(^{*}\right)$ indicates high overlap. $n=$ number of stomachs analyzed.

\begin{tabular}{lcccccc}
\hline Maturity stage and sex & $\begin{array}{c}\text { Juvenile } \\
\text { male }(n=54)\end{array}$ & $\begin{array}{c}\text { Adult male } \\
(n=90)\end{array}$ & $\begin{array}{c}\text { Juvenile } \\
\text { female }(n=90)\end{array}$ & $\begin{array}{c}\text { Adult female } \\
(n=81)\end{array}$ & $B_{\mathrm{A}}$ & $\mathrm{TP}$ \\
\hline Juvenile male & - & & & & 0.03 & 3.86 \\
Adult male & 0.34 & - & & & 0.15 & 3.49 \\
Juvenile female & 0.02 & 0.31 & - & & 0.03 & 3.85 \\
Adult female & $0.60^{*}$ & 0.47 & $0.56^{*}$ & - & 0.29 & 3.30 \\
& & & & & & \\
\hline
\end{tabular}

almost exclusively of $A$. iridescens to one including other crustaceans, cephalopods, and fishes. This diet change may be related 1) to hunting ability and skill and 2) to the morphology of the mouth and jaw (Luczkovich et al., 1995). In addition, this change in diet is reflected in the narrow trophic niche and the low dietary overlap between organisms of different size classes of sicklefin smoothhounds considered in this study (Table 5).

Because sharks exhibit characteristics typical of toplevel predators, they are thought to regulate prey communities through top-down control (e.g., Ferretti et al., 2010; Navia et al., 2010; Bornatowski et al., 2014b), together with habitat structure and ecosystem productivity (Estes et al., 2011; Ripple et al., 2014). Consequently, they are regarded as a key functional group (Frisch et al., 2016). Sharks are attributed important roles in marine food webs; however, few studies have provided evidence of the presumably high trophic positions of some shark species (Cortés, 1999).

Nonetheless, it is worth noting that not all sharks are top-level predators in a given ecosystem because the potential ecological functions of the species are related to a variety of factors, such as feeding habits, maximum body length, geographic and environmental range, the extent to which they are omnivorous, and vulnerability to predation by other sharks. Hence, the results of the study by Roff et al. (2016) indicate that sharks can exercise functions as high-level predators (maximum TL $>300 \mathrm{~cm}$, geographic 


\section{Table 5}

Dietary overlap between size classes, dietary niche breadth $\left(B_{\mathrm{A}}\right)$, and trophic position (TP) in sicklefin smoothhounds (Mustelus lunulatus) caught in the southeastern Pacific Ocean during November 2003-October 2004. The size classes are 60-90 cm in total length (TL, Size I), 90-120 cm TL (Size II), and 120-150 cm TL (Size III). An asterisk $(*)$ indicates high overlap. $n=$ number of stomachs analyzed.

\begin{tabular}{lccccc}
\hline $\begin{array}{l}\text { Size } \\
\text { class }\end{array}$ & $\begin{array}{c}\text { Size I } \\
(n=100)\end{array}$ & $\begin{array}{c}\text { Size II } \\
(n=182)\end{array}$ & $\begin{array}{c}\text { Size III } \\
(n=32)\end{array}$ & $B_{\mathrm{A}}$ & $\mathrm{TP}$ \\
\hline Size I & - & & & 0.02 & 3.93 \\
Size II & 0.12 & - & & 0.06 & 3.60 \\
Size III & 0.31 & $0.52^{*}$ & - & 0.13 & 2.73 \\
& & & & &
\end{tabular}

range of 100-1000 km, highly omnivorous), intermediate mesopredators (maximum TL 150-300 cm, geographic range $<10 \mathrm{~km}$, high trophic position), or small mesopredators (maximum TL $<100 \mathrm{~cm}$, geographic range $<10 \mathrm{~km}$, generally not omnivorous).

In accordance with these groupings, this study classified the sicklefin smoothhound as an intermediate mesopredatory shark (mean trophic position: 3.59 [SD 0.24]). This finding is consistent with the trophic position estimated by Cortés (1999) for the sicklefin smoothhound (3.9) and for other species of the genus Mustelus, for example, the brown smoothhound (3.6) and the gray smoothhound ( $M$. californicus, 3.5). Our results indicate that the sicklefin smoothhound could be an important factor if there is a substantial change in the populations of other large shark species (Bornatowski et al., 2014b).

In conclusion, the sicklefin smoothhound is an intermediate mesopredator that regulates the most abundant benthic crustacean populations along the coast of Ecuador. Generally, this species exhibits behavior and habitat segregation, and it is a selective predator that specializes in the consumption of highly abundant crustaceans off the coast of Ecuador. In this study, ontogenetic changes related to stage of maturity, size class, and time of year were observed in the diet of sicklefin smoothhounds. This study fills gaps in our knowledge of sharks in the waters of Ecuador and provides data for Ecuador's national plan of action for the conservation and management of sharks (MICIP, 2006).

\section{Acknowledgments}

The authors thank the fishermen and storekeepers of Tarqui Beach in Manta. C. Estupiñán-Montaño thanks the Fundación Alium Pacific, and F. Galván-Magaña thanks the Instituto Politecnico Nacional programs Estímulos al Desempeño de los Investigadores and Comisión de Operación y Fomento de Actividades Académicas. We thank I. Gambache and D. Edgar for editing our text for English.

\section{Literature cited}

Bohórquez-Herrera, J.

2006. Aspectos biológicos y pesqueros de los elasmobranquios capturados en el Parque Nacional Natural Gorgona y su área de influencia entre 2004 y 2005. B.S. thesis, 104 p. Univ. de Bogota Jorge Tadeo Lozano, Bogota, Colombia. [In Spanish.] [Available from website.]

Bornatowski, H., R. R. Braga, V. Abilhoa, and M. F. Corrêa.

2014a. Feeding ecology and trophic comparions of six shark species in coastal ecosystem off southern Brazil. J. Fish Biol. 85:246-263. Crossref

Bornatowski, H., A. F. Navia, R. R. Braga, V. Abilhoa, and M. F. M. Corrêa.

2014b. Ecological importance of sharks and rays in a structural foodweb analysis in southern Brazil. ICES J. Mar. Sci. 71:1586-1592. Crossref

Braga, R. R., H. Bornatowski, and J. R. Vitule.

2012. Feeding ecology of fishes: an overview of worldwide publications. Rev. Fish Biol. Fish. 22:915-929. Crossref

Brown, S. C., J. J. Bizarro, G. M. Cailliet, and D. A. Ebert.

2012. Breaking with tradition: redefining measures for diet description with a case study of the Aleutian skate Bathyraja aleutica (Gilbert 1896). Environ. Biol. Fish. 95:3-20. Crossref

Chirichigno F., N., and J. Vélez D.

1998. Clave para identificar los peces marinos del Peru, $2^{\text {nd }}$ ed., 491 p. Publ. Espec. Inst. Mar Peru, Callao, Peru. [In Spanish.] [Available from website.]

Clarke, M. R.

1986. A handbook for identification of cephalopod beaks, 269 p. Clarendon Press, Oxford, UK.

Clarke, K. R., and R. N. Gorley.

2006. PRIMER v6: user manual/tutorial, 18 p. PRIMER-E, Plymouth, UK.

Clothier, C. R.

1950. A key to some Southern California fishes based on vertebral characters. Calif. Dep. Fish Game, Fish Bull. $79,83 \mathrm{p}$.

Colwell, R. K.

2013. EstimateS: statistical estimation of species richness and shared species from samples. Vers. 9. User's guide and application. [Available from website.]

Compagno, L. J. V.

1984. FAO species catalogue. Vol. 4, Sharks of the world: an annotated and illustrated catalogue of shark species known to date. Parts 1 and 2 (Hexanchiformes to Lamniformes; Carcharhiniformes). FAO Fish. Synop. 125, vol. 4, 655 p. FAO, Rome.

Cortés, E.

1999. Standardized diet composition and trophic levels of sharks. ICES J. Mar. Sci. 56:707-717. Crossref

Del Rosario, J. B., and L. G. Abele.

1976. Description of the male and new distribution records for Acanthocarpus delsolari Garth 1973 (Decapoda, Calappidae) from de Pacific coast of Panama. Crustaceana 30:225-228. Crossref

Eder, E. B., and M. N. Lewis.

2005. Proximate composition and energetic value of demersal and pelagic prey species from the SW Atlantic Ocean. Mar. Ecol. Prog. Ser. 291:43-52. Crossref

Ellis, J. R., M. G. Pawson, and S. E. Shackley.

1996. The comparative feeding ecology on six species of shark and four species of ray (Elasmobranchii) in the north-east Atlantic. J. Mar. Biol. Assoc. U.K. 76:89-106. Crossref 
Estes, J. A., J. Terborgh, J. S. Brashares, M. E. Power, J. Berger, W. J. Bond, S. R. Carpenter, T. E. Essington, R. D. Holt, J. B. C. Jackson et al.

2011. Trophic downgrading of planet Earth. Science 333:301306. Crossref

Fernández, P.

1975. Estudio biológico y pesquero de algunas especies de tiburones carcharinidos del Pacífico colombiano. Ph.D. diss., 154 p. Univ. Jorge Tadeo Lozano, Bogota, Colombia. [In Spanish.]

Ferretti, F., B. Worm, G. L. Britten, M. R. Heithaus, and H. K. Lotze. 2010. Patterns and ecosystem consequences of shark declines in the ocean. Ecol. Lett. 13:1055-1071. Crossref

Fischer, W., F. Krupp, W. Schneider, C. Sommer, K. E. Carpenter, and V. H. Niem (eds.).

1995. Guía FAO para la identificación de especies para los Fines de Pesca. Pacífico centro-oriental: vertebrados, vols. 2 and 3, p. 647-1813. FAO, Rome. [In Spanish.]

Frisch, A. J., M. Ireland, J. R. Rizzari, O. M. Lönnstedt, K. A. Magnenat, C. E. Mirbach, and J.-P. A. Hobbs.

2016. Reassessing the trophic role of reef sharks as apex predators on coral reefs. Coral Reefs 35:459-472. Crossref

García-Godos, I.

2001. Patrones morfológicos del otolito sagitta de algunos peces óseos del mar Peruano. Bol. Inst. Mar Peru 20(12):1-83. [In Spanish.] [Available from website.]

Garth, J. S.

1973. New taxa of brachyuran crabs from deep water off western Peru and Costa Rica. Bull. South. Calif. Acad. Sci. 72:1-12.

Gómez, G. O., L. A. Zapata, R. Franke, and G. E. Ramos.

2003. Hábitos alimentarios de Mustelus lunulatus y $M$. henlei (Pisces: Triakidae) colectados en el Parque Nacional Natural Gorgona, Pacífico Colombiano. Bol. Invest. Mar. Cost. 32:219-229. [In Spanish.] Crossref

Hammer, Ø., D. A. T. Harper, and P. D. Ryan.

2001. PAST: paleontological statistics software package for education and data analysis. Palaeontol. Electron. 4(1), 9 p. [Available from website.]

Heithaus, M. R., A. Frid, A. J. Wirsing, and B. Worm.

2008. Predicting ecological consequences of marine top predator declines. Trends Ecol. Evol. 23:202-210. Crossref

Heithaus, M. R., A. Frid, J. J. Vaudo, B. Worm, and A. J. Wirsing.

2010. Unraveling the ecological importance of elasmobranchs. In Biology of sharks and their relatives II (J. C. Carrier, J. A. Musick, and M. R. Heithaus, eds.), p. 611-637. CRC Press, Boca Raton, FL.

Heithaus, M. R., J. J. Vaudo, S. Kreicker, C. A. Layman, M. Krützen, D. A. Burkholder, K. Gastrich, C. Bessey, R. Sarabia, K. Cameron et al.

2013. Apparent resource partitioning and trophic structure of large-bodied marine predators in a relatively pristine seagrass ecosystem. Mar. Ecol. Prog. Ser. 481:225-237. Crossref Hendrickx, M. E.

1995a. Cangrejo. In Guía FAO para la identificación de especies para los fines de la pesca. Pacífico centro-oriental, vol. 1: plantas e invertebrados (W. Fischer, F. Krupp, W. Schneider, C. Sommer, K. E. Carpenter, and K. E. Niem, eds.), p. 565-636. FAO, Rome. [In Spanish.]

1995b. Estomatópodos. In Guía FAO para la identificación de especies para los fines de la pesca. Pacífico centro-oriental, vol. 1: plantas e invertebrados (W. Fischer, F. Krupp, W. Schneider, C. Sommer, K. E. Carpenter, and U. H. Niem, eds.), p. 355-382. FAO, Rome. [In Spanish.]

1997. Los cangrejos braquiuros (Crustacea: Brachyura: Dromiidae, hasta Leucosiidae) del Pacifico Mexicano, 178 p. Com. Nac. Conocim. Uso Biodivers., Inst. Cienc. Mar Limnol., Univ. Nac. Auton. Mex., Mexico City, Mexico. [In Spanish.]

2000. The genus Munida Leach (Crustacea, Decapoda, Galatheidae) in the eastern tropical Pacific, with description of two new species. Biologie 79:163-192.

Hobson, K. A., and H. E. Welch.

1992. Determination of trophic relationships within a high Arctic marine food web using $\delta^{13} \mathrm{C}$ and $\delta^{15} \mathrm{~N}$ analysis. Mar. Ecol. Prog. Ser. 84:9-18. Crossref

Krebs, C. J.

1999. Ecological methodology, 745 p. Addison Wesley, Menlo Park, CA.

Lucifora, L. O., V. B. Garcia, R. C. Menni, A. H. Escalante, and N. M. Hozbor.

2009. Effects of body size, age and maturity stage on diet in a large shark: ecological and applied implications. Ecol. Res. 24:109-118. Crossref

Luczkovich, J. J., S. F. Norton, and R. G. Gilmore.

1995. The influence of oral anatomy on prey selection during the ontogeny of two percoid fishes, Lagodon rhomboides and Centropomus undecimalis. Environ. Biol. Fish. 44:79-95. Crossref

McCord, M. E., and S. E. Campana.

2003. A quantitative assessment of the diet of the blue shark (Prionace glauca) off Nova Scotia, Canada. J. Northwest Atl. Fish. Sci. 32:57-63.

MICIP (Ministerio de Comercio Exterior, Industrialización, Pesca y Competitividad).

2006. Plan de acción nacional para la conservación y manejo de tiburones de Ecuador (PAT-Ec), 44 p. MICIP, Quito, Ecuador. [In Spanish.]

Mora, E., V. Jurado, and W. Mendívez.

2010. Diversidad de macroinvertebrados en la plataforma continental de Ecuador. Rev. Cienc. Mar Limnol. 4(2):101116. [In Spanish.]

Moreno-Sánchez, X. G., O. Escobar-Sánchez, L. A. Abitia-Cardenas, and V. H. Cruz-Escalona.

2012. Diet composition of the sicklefin smooth-hound shark Mustelus lunulatus caught off El Pardito Island, Baja California Sur, Mexico. Mar. Biodivers. Rec. 5:e67. Crossref

Nations, D. J.

1975. The genus Cancer (Crustacea: Brachyura): systematics, biogeography and fossil record. Nat. Hist. Mus. Los Ang. Cty., Sci. Bull. 23, 104 p.

Navia, A. F., A. Giraldo, and P. A. Mejía-Falla.

2006. Notas sobre la biología y dieta del toyo vieja (Mustelus lunulatus) en la zona central de pesca del Pacífico colombiano. Invest. Mar. 34:217-222. [In Spanish.] Crossref

Navia, A. F., P. A. Mejia-Falla, and A. Giraldo.

2007. Feeding ecology of elasmobranch fishes in coastal waters of the Colombian Eastern Tropical Pacific. BMC Ecology 7:8. Crossref

Navia, A. F., E. Cortés, and P. A. Mejía-Falla.

2010. Topological analysis of the ecological importance of elasmobranch fishes: a food web study on the Gulf of Tortugas, Colombia. Ecol. Model. 221:2918-2926. Crossref

Pérez-Jiménez, J. C., and O. Sosa-Nishizaki.

2010. Determining reproductive parameters for population assessments of two smoothhounds (Mustelus californicus and Mustelus lunulatus) from the northern Gulf of California, Mexico. Bull. Mar. Sci. 86:3-13.

Philips, A. M., Jr.

1969. Nutrition, digestion, and energy utilization. In Fish physiology, vol. 1 (W. S. Hoar and D. J. Randall, eds.), p. 391-431. Academic Press, London. 
Pinkas, L., M. S. Olphant, and I. L. K. Iverson.

1971. Food habits of albacore, bluefin tuna, and bonito in California waters. Calif. Dep. Fish Game, Fish Bull. 152, $105 \mathrm{p}$.

Ripple, W. J., J. A. Estes, R. L. Beschta, C. C. Wilmers, E. G. Ritchie, M.

Hebblewhite, J. Berger, B. Elmhagen, M. Letnic, M. P. Nelson et al. 2014. Status and ecological effects of the world's largest carnivores. Science 343:1241484. Crossref

Roff, G., C. Doropoulos, A. Rogers, Y.-M. Bozec, N. C. Krueck, E. Aurellado, M. Priest, C. Birrell, and P. J. Mumby.

2016. The ecological role of sharks on coral reefs. Trends Ecol. Evol. 31:395-407. Crossref

Rojas, P. A.

2000. Contribución al conocimiento biológico de Mustelus lunulatus un recurso potencial para el Pacífico Colombiano. M.S. thesis, 59 p. Univ. del Valle, Cali, Colombia. [In Spanish.]

Rojas, J. R.

2006. Reproducción y alimentación del tiburón enano Mustelus dorsalis (Pisces: Triakidae) en el golfo de Nicoya, Costa Rica: elementos para un manejo sostenible. Rev. Biol. Trop. 54:861-971. [In Spanish.]

Sánchez, P.

2003. Cephalopods from off the Pacific coast of Mexico: biological aspects of the most abundant species. Sci. Mar. 67:81-90. Crossref
Samame, M., J. Castillo, and M. Espino.

1989. El tollo un recurso demersal. Algunos aspectos de la biología y pesquería del Mustelus whitneyi. Ch. Com. Perm. Pac. Sur. Rev. Pac. Sur. 313-326. [In Spanish.]

Smith, E. P., and T. M. Zaret.

1982. Bias in estimating niche overlap. Ecology 63:12481253. Crossref

Stevens, J. D., R. Bonfil, N. K. Dulvy, and P. A. Walker.

2000. The effects of fishing on sharks, rays, and chimeras (chondrichthyans), and the implications for marine ecosystems. ICES J. Mar. Sci. 57:476-494. Crossref

Tytler, P., and P. Calow.

1985. Fish energetics: new perspectives, 349 p. Johns Hopkins Univ. Press, Baltimore, MD.

Wearmouth, V. J., and D. W. Sims.

2008. Chapter 2. Sexual segregation in marine fish, reptiles, bird and mammals: behaviour patterns, mechanisms and conservation implications. Adv. Mar. Biol. 54:107-170. Crossref

Wehrtmann, I. S., and J. Cortés (eds.).

2009. Marine biodiversity of Costa Rica, Central America, 538 p. Springer, San Jose, Costa Rica.

Wolff, C. A.

1984. Identification and estimation of size from the beaks of eighteen species of cephalopods from the Pacific Ocean. NOAA Tech. Rep. NMFS 17, 50 p. 